\title{
EASTERN HEMLOCK RECOVERY FROM HEMLOCK WOOLLY ADELGID DAMAGE FOLLOWING IMIDACLOPRID THERAPY
}

\author{
By Ralph E. Webb ${ }^{1}$, J. Ray Frank ${ }^{2}$, and Michael J. Raupp ${ }^{3}$
}

\begin{abstract}
Hemlock woolly adelgid (Adelges tsugae) is a serious pest of hemlocks (Tsuga spp.) in the eastern United States. A variety of insecticides are capable of controlling hemlock woolly adelgid. The use of a systemic insecticide, imidacloprid, has gained widespread acceptance and use in the plant care industry. While several studies demonstrate the efficacy of imidacloprid in reducing adelgid populations, none have examined how hemlocks recover following imidacloprid therapy. Using specimen Tsuga canadensis trees in a residential landscape, we found that hemlocks recovered dramatically with new growth once the pressure of the adelgids was reduced following an application of imidacloprid. Most important, the response of trees to imidacloprid therapy differed in relation to their condition at the onset of the experiment. Trees with the healthiest, most foliated canopy improved the least following the reduction in adelgid populations. Trees with little new growth but no dieback recovered the quickest and most densely. Trees in the poorest condition at the onset recovered impressively but more slowly. Trees left untreated remained sparsely foliated, with dieback. These results confirm the value of imidacloprid therapy in improving the quality of hemlocks under attack by the hemlock woolly adelgid in urban forests.
\end{abstract}

Key Words. Adelges tsugae; Tsuga canadensis; plant health; systemic insecticide.

Eastern hemlock (Tsuga canadensis) and Carolina hemlock (T. caroliniana) are valued members of native forest communities and urban landscapes in the eastern United States. The hemlock woolly adelgid (Adelges tsugae) is the most important pest of these two species in both natural and managed settings. This pest was introduced into British Columbia from Asia sometime during the 1920s. It was observed in Virginia about 30 years later, and is now found in at least eleven states (Marion and Foster 2000; McClure et al. 2001).

Hemlocks often die rapidly after the onset of attack by hemlock woolly adelgid. In one study, McClure (1991) followed the fate of 30 mature hemlocks and found that all died within 4 years of the initial infestation. However, our observations support those of McClure et al. (2001) that some trees, although heavily damaged by the adelgid, continue to live for many years after attack while sustaining adelgid populations. Some recovery is observed, but trees often lose the majority of lower branches-leaving a thin high canopy (McClure et al. 2001).
Early attempts to control the hemlock woolly adelgid revealed good efficacy of foliar insecticides including insecticidal soap and oil as well as numerous petrochemical insecticides (McClure 1987, 1988). Thorough coverage was the key to effective control with foliar contact insecticides. More recently, McClure (1992) provided convincing evidence that several systemic insecticides including oxydemetonmethyl, bidrin, and acephate provided excellent levels of control when injected or implanted through the bark of the tree. Steward and Horner (1994) demonstrated that imidacloprid applied as a soil injection provided excellent control of hemlock woolly adelgid on established eastern hemlocks in a formal public garden. Steward and Horner (1994), Marion and Foster (2000), and McClure et al. (2001) noted that soil applications had advantages over bark injections or implants in that they do not wound the bark of the tree. McClure et al. (2001) also noted that a healthy sap flow was vital to transporting and distributing systemic insecticides from the soil throughout the canopy of the tree. Severe damage by the adelgid reduce the ability of hemlocks to transport and distribute imidacloprid.

Our objectives were twofold. First, we wanted to document the recuperative response of hemlocks infested by adelgids following the application of imidacloprid through the soil. Second, we wanted to determine if the initial condition of the hemlock affected its ability to respond to treatment.

\section{MATERIALS AND METHODS}

Hemlocks used in this study were growing in a residential landscape in Frederick County, Maryland, U.S. Trees ranged in size from 13 to $58 \mathrm{~cm}$ diameter at breast height (dbh, $1.4 \mathrm{~m}$ ) at the onset of the study. All had been infested with hemlock woolly adelgid for several years. Prior to the application of imidacloprid on March 31, 1999, the condition of all trees was evaluated by examining their canopies for new growth, needle loss, and dieback. Trees were rated and placed into one of three categories. Healthy trees were those that had new growth and little needle loss. New growth was observed on at least $10 \%$ of the terminals, and some trees had new growth on virtually all terminals. There were five in this category. The second category, designated poor, included trees with little or no new growth ( $<10 \%$ of terminals) and 
little or no dieback or needle loss. There were seven in this category. The third category was designated trees with dieback. They had no new growth and scattered-towidespread needle loss with attendant dieback. This category contained seven trees.

At the time trees were categorized, each tree was also rated according to the number of terminals bearing new growth. This rating system was used to quantify changes in tree health over the course of the study. New growth was visually estimated by two experienced observers, a horticulturist (JRF) and an entomologist (REW). Trees with $<10 \%$ of terminals bearing new growth were rated as 1 , trees with $10 \%$ to $25 \%$ of terminals bearing new growth were rated as 2 , trees with $26 \%$ to $50 \%$ of terminals bearing new growth were rated as 3, trees with $51 \%$ to $75 \%$ of terminals bearing new growth were rated as 4 , and trees with $>75 \%$ of terminals bearing new growth were rated as 5 . All trees were rated the day that imidacloprid applications were made and again at 144,434 , and 816 days after treatment.

Four trees in the poor category were left untreated and the adelgids uncontrolled. All remaining trees were treated with imidacloprid on March 31, 1999. Imidacloprid was applied as a soil drench of Merit ${ }^{\circledR} 75 \mathrm{WP}$ according to the high label rate $(=2 \mathrm{~g}$ product in $0.95 \mathrm{~L}$ solution per $2.5 \mathrm{~cm}$ dbh) (Bayer 1998). Imidacloprid was mixed and applied in a watering can using the soil drench method (Bayer 1998). The soil at the site was moist and did not require supplemental irrigation at the time of application.

At the conclusion of the study, 816 days after treatment, the overall appearance of each tree was rated. Trees were rated numerically from best (10) to worst (0) as follows. Trees of excellent appearance were rated 10 or 9 . Trees in good condition were rated 8 to 6 . Trees with increasing levels of dieback were rated 5 to 3 . Trees half dead were rated 2 , mostly dead 1 , and all dead 0 . The dbh of each tree was measured to the nearest $\mathrm{cm}$ at the beginning and at the conclusion of the study.

In addition to tracking changes in the health and appearance of the trees, we also tracked changes in the abundance of hemlock woolly adelgid. Counts of adelgids were restricted to the terminals of the new growth. A "terminal" generally included the central leader and several side tips growing off the leader. Prior to the application of imidacloprid on March 31, 1999, the abundance of adelgids on each tree was rated using the following criteria. Trees with adelgids on 1 to 2 terminals were given a rating of 1 , trees with adelgids on 3 to 5 terminals received a 2, trees with adelgids on more than 5 terminals but less than $25 \%$ of the total received a 4 , trees with adelgids on $25 \%$ to $50 \%$ of terminals received a 5 , trees with adelgids on $51 \%$ to $75 \%$ of terminals received a 6 , trees with adelgids on $76 \%$ to $90 \%$ of terminals received a 7 , trees with adelgids on $91 \%$ but less than $100 \%$ of terminals received an 8 , trees with adelgids present on all terminals received a 9 , and a rating of 10 was given to one tree with extraordinarily high densities of adelgids on every terminal.

The change in the abundance of hemlock woolly adelgids on each tree was determined by subtracting the abundance rating at the end of the study at day 816 from its abundance rating at the beginning on day 0 . We then compared the change in rating across categories of trees as given below. Variances in these differences were heteroscadastic among tree categories, and homogeneity of variance could not be achieved through transformation of the data. Therefore, the changes in ratings were compared among treatments with a Kruskal-Wallis nonparametric analysis of variance (Zar 1999). Differences among categories were resolved following the Kruskal-Wallis analysis with a Nemenyi test (Zar 1999).

The change in the health of hemlocks indicated by the production of new growth was evaluated by subtracting the new growth rating of each tree at the beginning of the study from the rating at the end of the study, 816 days after treatment. Increases in the amount of new growth indicated by a change in rating were compared with an analysis of variance followed by a Bonferroni (Dunn) test to resolve treatment means (Zar 1999). The change in the health of hemlocks indicated by the caliper of the tree was evaluated by subtracting the dbh at the beginning of the study from the $\mathrm{dbh}$ at the end. Increases in the dbh were compared with an analysis of variance followed by a Bonferroni (Dunn) test to resolve treatment means (Zar 1999). The final appearances of the trees at the completion of the study were evaluated by comparing the appearance ratings among categories with an analysis of variance followed by a Bonferroni (Dunn) test to resolve treatment means (Zar 1999).

\section{RESULTS AND DISCUSSION}

The abundance of adelgids on all treated hemlocks declined significantly compared to untreated hemlocks (Chi-square = 12.99; $\mathrm{df}=3 ; \mathrm{P}<0.005$ ) (Figure 1). However, trees with the highest levels of adelgids at the onset of the study, those in the healthy category, experienced the greatest reduction in adelgid abundance (Figures 1 and 2). These trees changed from having adelgids on about $90 \%$ of their terminals to being virtually free of adelgids (Figure 2). Trees in the poor health category also experienced reductions in adelgids (Figures 1 and 2). Adelgids infested between one quarter and one half of the terminals at the onset of the study but were found on only one or two terminals at the end (Figure 2). Even the most unhealthy trees, those in a state of dieback, experienced significant reductions in adelgids following imidacloprid therapy (Figures 1 and 2). These sickly trees housed few adelgids at the onset of the study presumably due to their advanced state of decline (Figure 2) (McClure 1991). However, by the end of the experiment even these trees were virtually free of adelgids (Figure 2 ). These results 
are encouraging because they indicate that trees with significant dieback and needle loss are still competent to absorb imidacloprid from the soil and transport it in lethal levels to the canopy. The efficacy of imidacloprid in controlling adelgid in this study supports the findings of Steward and Horner (1994).

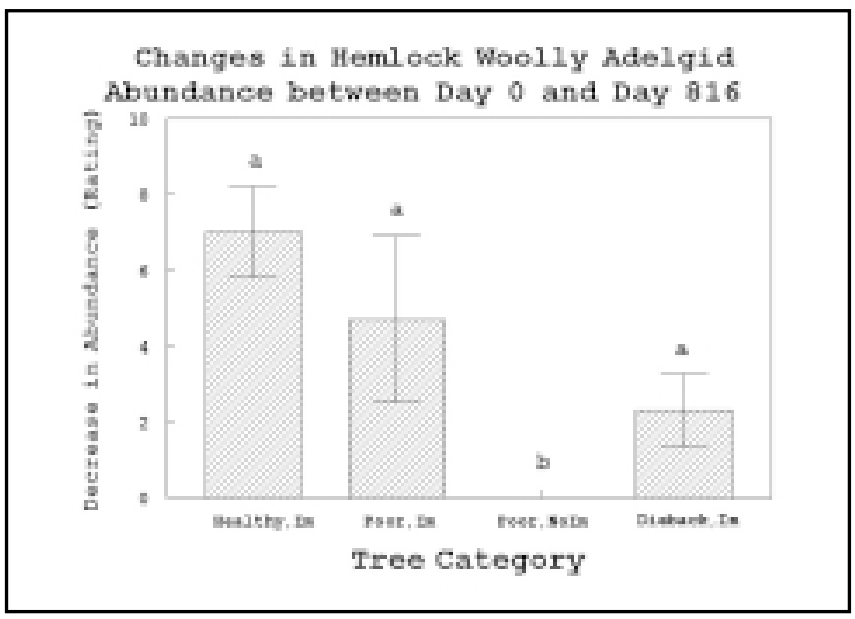

Figure 1. Decrease in the abundance ratings of hemlock woolly adelgid on three categories of eastern hemlock prior to and 816 days after the application of imidacloprid. Tree health categories are: Healthy = trees with new growth at the beginning of the study; Poor = little or no new growth but with no dieback; Dieback = no new growth, with dieback and needle loss. Im = imidacloprid application; NoIm = no imidacloprid. Bars represent means, and vertical lines represent standard errors. Means that share a letter do not differ by a Nemenyi test $(P=0.05)$.

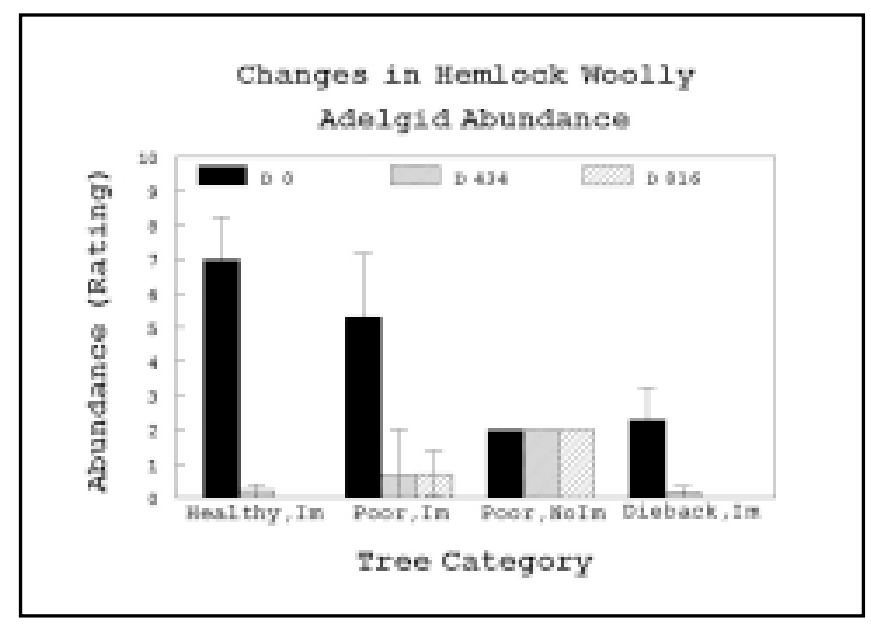

Figure 2. Abundance ratings of hemlock woolly adelgid on eastern hemlock at 0 days, at 434 days, and at 816 days after the application of imidacloprid. Health categories are as in Figure 1. Bars represent means. and vertical lines represent standard errors.
Changes in the health of hemlocks in response to imidacloprid therapy were most dramatic for trees in poor health or in a state of dieback. Trees in these categories generated significantly more new growth than untreated trees or those in a healthy condition at the onset of the experiment $(F=9.62 ; \mathrm{df}=3,14 ; P<0.001)$. Poor-category trees had virtually no new growth at the onset of the study (Figure 3). The poor-category trees, those with no new growth but little needle loss or dieback, responded rapidly to the application of imidacloprid. Within the first 144 days after treatment new growth was present on $26 \%$ to $75 \%$ of the terminals. Hemlocks in the least healthy category, those with dieback and needle loss, recovered more slowly, but by day 434 exhibited new growth on $26 \%$ to $75 \%$ of terminals (Figure 3). Untreated trees exhibited little or no new growth throughout the course of the study (Figure 3). These results compliment those of McClure (1992), who demonstrated a significant increase in the biomass of hemlocks treated with systemic insecticides. Like McClure (1992), we attribute the recovery of hemlocks to the reduction in adelgid feeding pressure following the application of systemic insecticides. It is noteworthy that in McClure's (1992) studies, the recovery of severely damaged trees was less than that of trees less damaged, but in our study, severely damaged trees recovered well-albeit the recovery period was longer.

We could not detect a significant difference in the increase in caliper of trees in the different health categories following the application of imidacloprid $(F=2.82 ; \mathrm{df}=3,14$; $P<0.08$ ) (Figure 4). However, there was a clear trend for trees released from adelgid pressure to increase in caliper. Trees that had sustained the least damage generally experienced the largest gains (Figure 4).

The final rating of tree appearance on day 816 demonstrated that all trees treated with imidacloprid differed significantly from trees left untreated $(F=5.35 ; \mathrm{df}=3,14 ; \mathrm{P}$ $<0.01$ ) (Figure 5). At the conclusion, all trees treated with imidacloprid were rated in good condition, while those untreated received poor ratings due to continued dieback and needle loss.

The importance of these findings is twofold. First, we have confirmed a high level of long-lasting control of hemlock woolly adelgid afforded by a single administration of the systemic insecticide imidacloprid. Second, we have demonstrated that after adelgid populations are suppressed, hemlocks will recover by producing new growth on most branches. Even trees that have experienced a cessation of new growth with attendant needle loss and dieback will experience dramatic recovery following imidacloprid therapy. In less than 3 years, the appearance of these trees will approximate those of hemlock less severely damaged. 


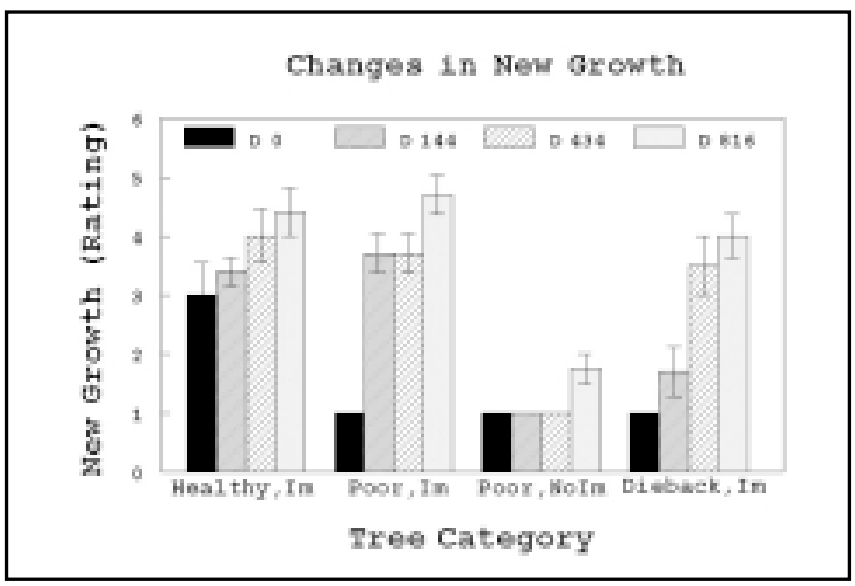

Figure 3. Growth rating of eastern hemlock at day 0 , and changes in the new growth ratings at 144 days, at 434 days, and at 816 days after imidacloprid application. Tree health categories are as in Figure 1. Bars represent means, and vertical lines represent standard errors.

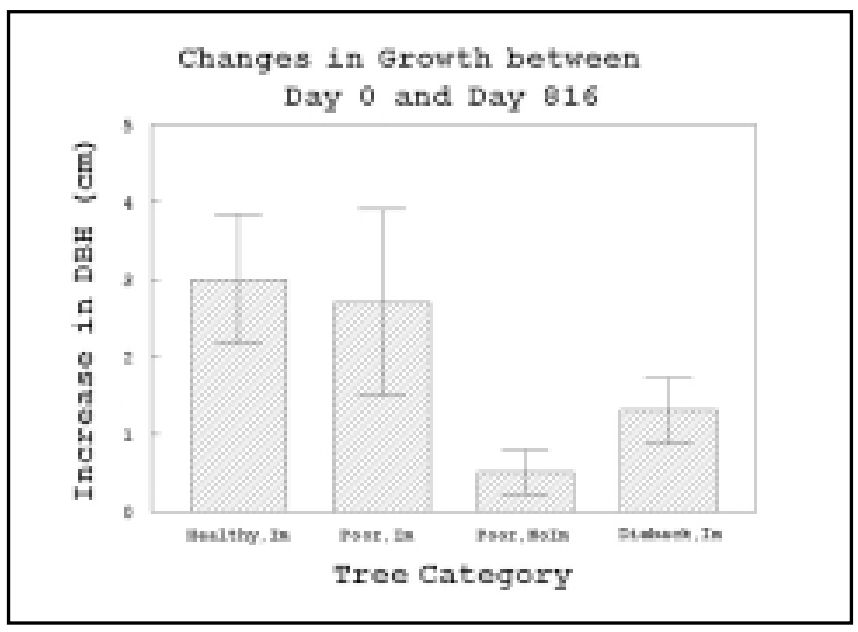

Figure 4. Increase in the dbh of eastern hemlock 816 days after the application of imidacloprid. Tree health categories are as in Figure 1. Bars represent means, and vertical lines represent standard errors. Means that share a letter do not differ by a Bonferroni test $(P=0.05)$.

\section{LITERATURE CITED}

Bayer. 1998. Merit: Control of the Hemlock Woolly Adelgid Using Merit. Product information bulletin ME 98101.

Kansas City, MO. 10 pp.

Marion, D.F., and D. Foster. 2000. Woolly adelgid hits New

England. Golfweeks Superintendents News. 2(4):9.

McClure, M.S. 1987. Biology and Control of Hemlock

Woolly Adelgid. Bulletin of the Connecticut Agricultural Experiment Station, 851. New Haven, CT. 8 pp.

—. 1988. Hemlock woolly adelgid control using foliar sprays. Insect. Acaricide Tests 13:378.

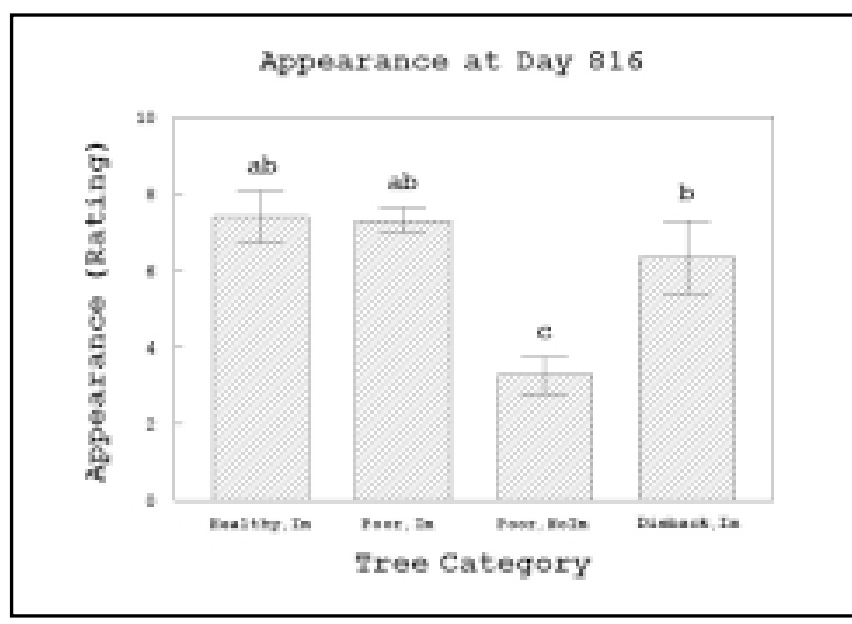

Figure 5. Appearance ratings of eastern hemlock 816 days after the application of imidacloprid. Tree health categories are as in Figure 1. Bars represent means, and vertical lines represent standard errors. Means that share a letter do not differ by a Bonferroni test $(P=0.05)$.

1991. Density-dependent feedback and population cycles in Adelges tsugae (Homoptera: Adelgidae) on Tsuga canadensis. Environ. Entomol. 20:258-264.

1992. Effects of implanted and injected pesticide and fertilizers on the survival of Adelges tsugae (Homoptera: Adelgidae) and on the growth of Tsuga canadensis. J. Econ. Entomol. 85:468-472.

McClure, M.S., S. Salom, and K.S. Shields. 2001. Hemlock Wooly Adelgid. Forest Health Technology Enterprise Team. U.S. Forest Service Publication FHTET-2001- 03. Morgantown, WV. 14 pp.

Steward, V.B., and T.A. Horner. 1994. Control of hemlock woolly adelgid using soil injections of systemic insecticides. J. Arboric. 20:287-88.

Zar, J. 1999. Biostatistical Analysis. Prentice Hall, Upper Saddle River, NJ. 


\author{
${ }^{1 *}$ Research Entomologist \\ Chemicals Affecting Insect Behavior Laboratory \\ Beltsville Agricultural Research Center \\ Agricultural Research Service \\ United States Department of Agriculture \\ Beltsville, MD 20705, U.S.

\section{${ }^{2}$ Ornamentals Manager} \\ IR-4 Project \\ 6916 Boyers Mill Road \\ New Market, MD 21774, U.S. \\ ${ }^{3}$ Professor \\ Department of Entomology \\ University of Maryland \\ College Park, MD, 20742, U.S. \\ *Corresponding author.
}

Résume. La cochenille floconneuse de la pruche, Adelges tsugae, est un insecte sérieux chez les pruches, Tsuga spp., dans l'Est des États-Unis. Une variété d'insecticides sont capables de contrôler la cochenille floconneuse de la pruche. Lutilisation d'un insecticide systémique, l'imidacloprid, est de plus en plus accepté et utilisé dans l'industrie de l'entretien des végétaux. Alors que plusieurs études démontrent l'efficacité de l'imidacloprid pour diminuer les populations de cochenilles, aucune n'a encore examiner comment les pruches se remettent de la thérapie à l'imidacloprid. Au moyen de spécimens de Tsuga canadensis en milieu résidentiel aménagé, nous avons découvert que les pruches s'en remettaient dramatiquement bien lors de la période de croissance, et ce une fois que la pression des cochenilles floconneuses était diminuée après l'application d'imidacloprid. Le plus important est que la réponse des arbres à la thérapie par l'imidacloprid différait selon la condition des arbres sur le site de l'attaque. Les arbres avec la masse foliaire la plus dense et la plus en santé étaient ceux qui avaient éprouvé le moins de perte de croissance après la diminution des populations de cochenilles floconneuses. Les arbres avec une croissance plus faible, mais sans qu'il y ait pour autant de mortalité aux extrémités des branches, étaient ceux qui s'en remettaient le plus rapidement et avec une augmentation de densité de cime la plus forte. Les arbres dont la condition était la plus pauvre sur le site de l'attaque s'en remettaient de manière impressionnante, mais plus lentement. Les arbres laissés sans traitement demeuraient peu denses en aiguilles et comportaient des extrémités de branches mortes. Ces résultats confirment la valeur de la thérapie à l'imidacloprid pour améliorer la qualité des pruches qui sont attaquées par la cochenille floconneuse de la pruche en milieu urbain.

Zusammenfassung. Adelges tsugae ist in den östlichen Vereinigten Staaten ein bedeutender Parasit an Tsuga spp. Eine Reihe von Insektiziden sind in der Lage, diesen Schädling zu kontrollieren. Die Anwendung von einem systemischen Insektizid, Imidacloprid, fand in der Pflanzenindustrie weitverbreitete Akzeptanz und Anwendung. Während einige Studien die Effektivität von Imidacloprid bei der Kontrolle des Schädlings demonstrieren, so haben doch keine bislang untersucht, wie die Tsuga sich anschließend regeneriert. In einer bewohnten Landschaft wurden Exemplare von T. canadensis, untersucht und ein dramatischer Neuwuchs nach der erfolgreichen Behandlung und Reduktion der Schädlinge festgestellt. Und wichtig festzustellen war, dass die Bäume unterschiedlich in Abhängigkeit von ihrer Kondition zu Beginn des Experiments reagierten. Bäume mit dem gesündesten Laub und dichtester Belaubung verbesserten sich am wenigsten. Bäume mit wenig Neuwuchs aber keinen Absterbeerscheinungen erholten sich sehr schnell und sehr dicht. Bäume mit ganz schlechtem Erscheinungsbild erholten sich erstaunlich, aber langsam. Unbehandelte Bäume blieben spärlich belaubt und starben zurück. Diese Ergebnisse unterstützen den Wert der Imidacloprid-Therapie bei der Qualitätsverbesserung von Tsuga spp.

Resumen. El aldégido del abeto americano, Adelges tsugae, es una fuerte plaga de los abetos, Tsuga spp., en el este de los Estados Unidos. Una variedad de insecticidas es capaz de controlar al insecto. El uso del insecticida sistémico imidacloprid ha ganado aceptación y uso en la industria del cuidado de las plantas. Mientras varios estudios demuestran la eficacia de imidacloprid en la reducción de las poblaciones del aldégido, ninguno ha examinado la manera como se recuperan los abetos después de la terapia con imidacloprid. Utilizando especimenes del árbol Tsuga canadensis en un área residencial, se encontró que los abetos se recobraron de manera dramática con nuevo crecimiento, una vez que la presión de los aldégidos fue reducida con la aplicación de imidacloprid. Además, la respuesta de los árboles a la terapia de imidacloprid difirió con relación a su condición en el inicio del experimento. Los árboles más saludables, con mayor follaje mejoraron menos después de la reducción de las poblaciones del insecto. Los árboles con poco y nuevo crecimiento pero sin muerte regresiva se recobraron rápidamente y más densamente. Los árboles en la condición más pobre al principio se recobraron más lentamente. Los árboles sin tratar presentaron muerte regresiva. Estos resultados confirman el valor de la terapia de imidacloprid en el mejoramiento de la calidad de los abetos bajo el ataque del aldégido en bosques urbanos. 